\title{
PHARMACOKINETIC CONVERSION STUDY OF A NEW CYCLOSPORINE FORMULATION IN STABLE ADULT RENAL TRANSPLANT RECIPIENTS
}

\author{
František Perlík $k^{\mathrm{a}}$, Marwan A. Masri ${ }^{\mathrm{b}}$, M. Rost ${ }^{\mathrm{c}}$, Vojtěch Kamarád ${ }^{\mathrm{d}}$
}

\author{
a Institute of Pharmacology, $1^{\text {st }}$ Faculty of Medicine, Charles University, Prague, Czech Republic \\ ${ }^{b}$ Rizk Hospital, Beirut, Lebanon \\ Univerity of South Bohemia, České Budějovice, Czech Republic \\ d Clinical Department R\&D, IVAX-CR, a.s., Opava, Czech Republic \\ e-mail:fperl@lf1.cuni.cz
}

Received: October 6, 2005; Accepted (with revisions): November 30, 2005

Key words: Cyclosporine A/Comparative study Equoral vs. Neoral/Bioequivalence

Cyclosporine A (CyA) is a standard component of immunosuppressive regimens. It is a critical-dose drug for which a minor change in absorption can have important clinical consequences. The aim of the study was to compare the pharmacokinetics and safety of the new generic CyA formulation, Equoral ${ }^{\circledR}$ capsules, after a switch from original formulation, Neoral ${ }^{\circledR}$ capsules, in seventy stable adult renal transplant recipients. The extent and rate of pharmacokinetic parameters for bioequivalence were compared in a non-randomized, steady-state clinical study with fixed non-replicate study design. Pharmacokinetic analysis of CyA have shown that both the rate and extent of absorption of Equoral ${ }^{\circledR}$ does not differ significantly from that of Neoral ${ }^{\circledR}$. At identical dosing, the new formulation was found to have geometric means of $\mathrm{C}_{\max } 717 \mathrm{ng} / \mathrm{ml}$ and $\mathrm{AUC} \tau 3108 \mathrm{ng} / \mathrm{ml} . \mathrm{h}$, while corresponding results of comparator were $725 \mathrm{ng} / \mathrm{ml}$ and AUC $\tau 3039 \mathrm{ng} / \mathrm{ml}$.h, respectively. The $90 \%$ confidence intervals of $\mathrm{C}_{\max }$ and AUC $\tau$ were within 80$125 \%$ interval of the mean values. The results suggest that Equoral ${ }^{\circledR}$ capsules can be used as an alternative treatment to $\mathrm{Neoral}^{\circledR}$ capsules in CyA regimen.

\section{ABBREVIATIONS}

ANOVA Analysis of variance

AUC Area under the curve

AUMC Area under the $1^{\text {st }}$ moment concentration-time curve

BTL Blood trough level

C0, C2 Concentration before and 2 hrs after drug administration

$\mathrm{C}_{\max } \quad$ Maximum concentration

$\mathrm{C}_{\min } \quad$ Minimun concentratiom

CyA Cyclosporine A

$\lambda \quad$ Terminal elimination rate constant

MRT Mean Residence Time

PK Pharmacokinetic

PTF Peak-trough-fluctuation

SD Standard deviation

ss steady state

$t_{1 / 2 \mathrm{el}} \quad$ Half-life of drug elimination

\section{INTRODUCTION}

Cyclosporine, a calcineurine inhibitor, is a potent immunosuppressant with an important role in organ and tissue transplantation. It is a drug with a narrow therapeutic range and therapeutic drug monitoring is important ${ }^{1}$.
Pharmacokinetic and pharmacodynamic data suggest that the absorption phase in the first hours after CyA oral administration is an area of the greatest intra- and interpatient variability. The latter depend upon the patient's individual ability to absorb CyA from the gastrointestinal tract, given possible intestinal diseases, such as mild diarrhea, intestinal surgery or bowel length, and upon subpopulation variability ${ }^{2-4}$. Different drug formulations of CyA also represent a very important factor in pharmacokinetic variability. Standard guidelines issued by the Committee for Proprietary Medicinal Products for bioequivalence testing in Europe 5 consider two medicinal products as bioequivalent if their bioavailibility after administration at the same molar dose is similar to such an extent that their efficacy and safety will be essentially the same. Recently, Equoral ${ }^{\circledR}$ (IVAX, Miami, Fla, USA), a new formulation of CyA, was tested in a bioequivalence study after single dose administration in healthy volunteers. Equoral ${ }^{\circledR}$ proved to be bioequivalent to Neoral ${ }^{\circledR}$ (Novartis, Basle, Switzerland) with respect to the extent and the rate of absorption and the drug was marketed ${ }^{6}$. However, standard bioequivalence criteria do not address differences in CyA pharmacokinetics between transplant recipients and healthy volunteers.

The aim of this study was to compare the pharmacokinetics and safety of the new generic CyA formulation - Equoral ${ }^{\circledR}$ capsules - after a switch from the original 
formulation, Neoral ${ }^{\circledR}$ capsules, in stable adult renal transplant recipients. For this reason, a comparative, non-randomized, steady-state study with fixed non-replicate study design was carried out.

\section{MATERIAL AND METHODS}

\section{Subjects}

Three centers recruited patients for the investigation after the study protocol had been approved by the local Ethics Committee. Informed written consent was obtained from all study participants. Patient care and the way the study was conducted complied with good clinical practice and the Declaration of Helsinki guidelines.

We included stable renal transplant recipients aged more than 18 years who had undergone renal transplantation of cadaveric or living donors. Patient were included if they had had no rejection episode in the past 6 months, had a stable serum creatinine in the past 3 months with no trend to increase, were normotensive, maintained on CyA in double or triple combination with prednisone, azathioprine, mycophenolate mofetil, had a stable dose of CyA (Sandimmun Neoral ${ }^{\circledR}<8 \mathrm{mg} / \mathrm{kg} /$ day, BID) over the previous 14 days prior to entry, had stable concomitant medication 14 days prior to entry. In addition, all patients had three last whole blood CyA trough levels in the range of 70-200 ng/ml. Patients were excluded if they had a severe clinically relevant coexisting disease such as significant cardiac disease or had received a drug which might influence CyA pharmacokinetics, history of alcohol or drug abuse, malignancy, CMV infection or other unstable medical condition, had received any investigational drugs within the preceding months, were pregnant or lactating, or were tested positively for human immunodeficiency virus.

\section{Design}

Study design and schedule of assessments are depicted in Figure 1.

Subjects on stable Sandimmun ${ }^{\circledR}$ Neoral $^{\circledR}$ capsules BID therapy were switched to Equoral ${ }^{\circledR}$ capsules BID at an equivalent dosage (milligrams: milligrams) on day 15 in the morning and then re-switched at an equivalent dosage (milligrams: milligrams) on day 29 in the morning. Individual blood CyA trough levels were checked at entry and on days 18 and 35 to be within therapeutic range 70-200 ng/mL. The sparse sampling, before drug intake, and at 2 hours after drug intake, were measured on day 0 and controlled on day 21. Blood sampling for pharmacokinetic measurement was performed on days 14 and 28. In the afternoon before each 12-hour PK the subjects were admitted and hospitalized in the clinical unit until discharged after the 12-hour pharmacokinetic study. During each pharmacokinetic part of the study 12 venous blood samples were taken; pre-dose and at times $0.5 \mathrm{~h} ; 1 \mathrm{~h} ; 1.5 \mathrm{~h}$; $2 \mathrm{~h} ; 3 \mathrm{~h} ; 4 \mathrm{~h} ; 5 \mathrm{~h} ; 6 \mathrm{~h} ; 8 \mathrm{~h} ; 10 \mathrm{~h}$ and $12 \mathrm{~h}$ after the regular morning dose of $\mathrm{CyA}$ at the end of the first and second study period.

Table 1. Summary of the statistical analysis of multiple-dose pharmacokinetic characteristics

\begin{tabular}{|c|c|c|c|}
\hline $\begin{array}{c}\text { Pharmacokinetic } \\
\text { characteristic }\end{array}$ & $\begin{array}{l}\operatorname{Neoral}^{\circledR}(\mathrm{R}) \\
\text { Geometric mean,n }=12 \\
\exp (\text { mean }[\ln ] \pm \operatorname{sd}[\ln ])\end{array}$ & $\begin{array}{c}\text { Equoral }^{\circledR}(\mathrm{T}) \\
\text { Geometric mean,n }=12 \\
\exp (\operatorname{mean}[\ln ] \pm \operatorname{sd}[\ln ])\end{array}$ & $\begin{array}{c}\mathrm{T} / \mathrm{R} \\
\text { Geometric mean } \\
\text { 90\%-confidence interval }\end{array}$ \\
\hline $\mathrm{AUC} \tau(\mathrm{ng} / \mathrm{ml} . \mathrm{h})$ & $3039(1738,5314)$ & $3108(1821,5304)$ & $1.02(0.99,1.06)$ \\
\hline $\mathrm{C} \max (\mathrm{ng} / \mathrm{ml})$ & $725(461,1139)$ & $717(449,1147)$ & $0.99(0.93,1.05)$ \\
\hline $\mathrm{C} \min (\mathrm{ng} / \mathrm{ml})$ & $104(56,193)$ & $107(56,205)$ & $1.03(0.98,1.08)$ \\
\hline PTF (\%) & $241(173,337)$ & $229(152,345)$ & $0.95(0.90,1.01)$ \\
\hline $\operatorname{MRT}(\mathrm{h})$ & $8.01(5.47,11,77)$ & $8.40(6.33,11.15)$ & $1.05(0.89,1.21)$ \\
\hline
\end{tabular}

Table 2. Number of patients with different absorption profile of cyclosporine

\begin{tabular}{|c|c|c|c|}
\hline Absorption profile & $\mathrm{C}_{2} / \mathrm{C}_{0}$ & Neoral $^{\circledR}$ & Equoral $^{\circledR}$ \\
\hline Low & $<3.6$ & $17(24.3 \%)$ & $10(14.3 \%)$ \\
\hline Intermediate & $3.6-7.6$ & $40(57.1 \%)$ & $46(65.7 \%)$ \\
\hline High & $>7.6$ & $13(18.6 \%)$ & $14(20.0 \%)$ \\
\hline Total & & $70(100 \%)$ & $70(100 \%)$ \\
\hline
\end{tabular}

$\chi^{2}=2.27, \mathrm{NS}$. 
III
Study period I
Study period II
Study period

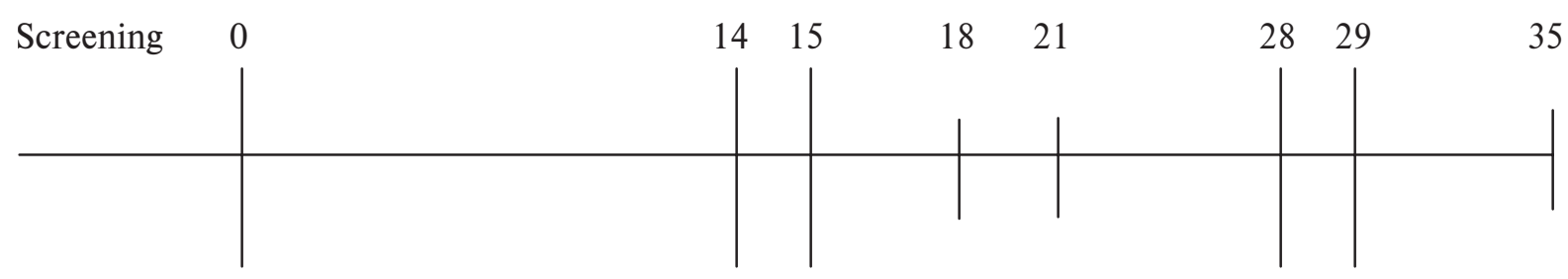

BTL

$\mathrm{C} 0, \mathrm{C} 2$

BTL

BTL

$\mathrm{C} 0, \mathrm{C} 2$

\section{NEORAL}

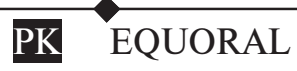

PK NEORAL

Fig. 1. Study design and schedule of assessments (see abbreviations).

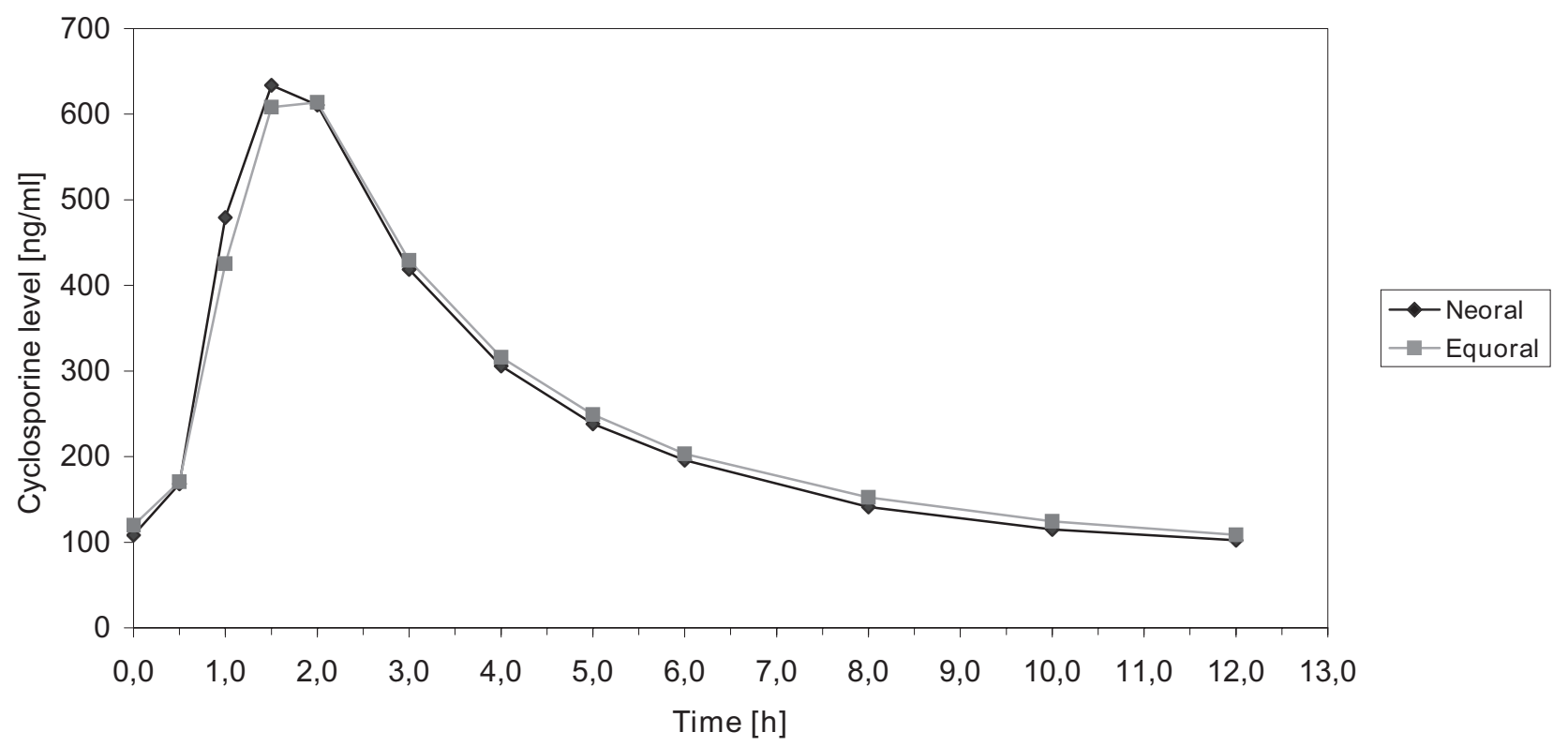

Fig. 2. Geometric means of the concentration/time profiles of cyclosporine.

Safety parameters were monitored at each visit (vital signs, physical examinations, number of routine laboratory parameters, incidence of adverse events).

\section{Analytical Methodology}

CyA blood levels were analyzed by a validated TDx Abbot monoclonal specific antibody methodology (limit of quantification - $25 \mathrm{ng} / \mathrm{ml}$ ) in the local Immunoanalytical Laboratories of each particular center.

\section{Pharmacokinetic and Statistical Analysis}

The following extent and rate oriented pharmacokinetic parameters for bioequivalence were individually analyzed by model independent analysis:
- Area under the blood concentration/time curve over one steady-state dosing interval: AUC $\tau$ (determined by the trapezoidal rule up to the last sampling point above the limit of quantification)

- Maximum and minimum blood concentration in the dosing interval $\mathrm{C}_{\text {max-ss }}, \mathrm{C}_{\text {min-ss }}$, (taken directly from the blood concentration/time curve)

- Peak-Trough Fluctuation: $\mathrm{PTF}=\left(\mathrm{C}_{\text {max-ss }}-\mathrm{C}_{\text {min-ss }}\right) / \mathrm{C}_{\mathrm{av}-\mathrm{ss}}$, where $\mathrm{C}_{\text {av-ss }}=\mathrm{AUC} \tau / \tau$

- Terminal elimination rate constant: $\lambda_{z}$ (estimated by log-linear least squares regression analysis of the terminal part of the blood concentration/time curve)

- Half-life of drug elimination during terminal phase: $\mathrm{t}_{1 / 2 \mathrm{el} .}=\ln 2 / \lambda_{\mathrm{z}}$

- Mean Residence Time: MRT = AUMC/AUC 


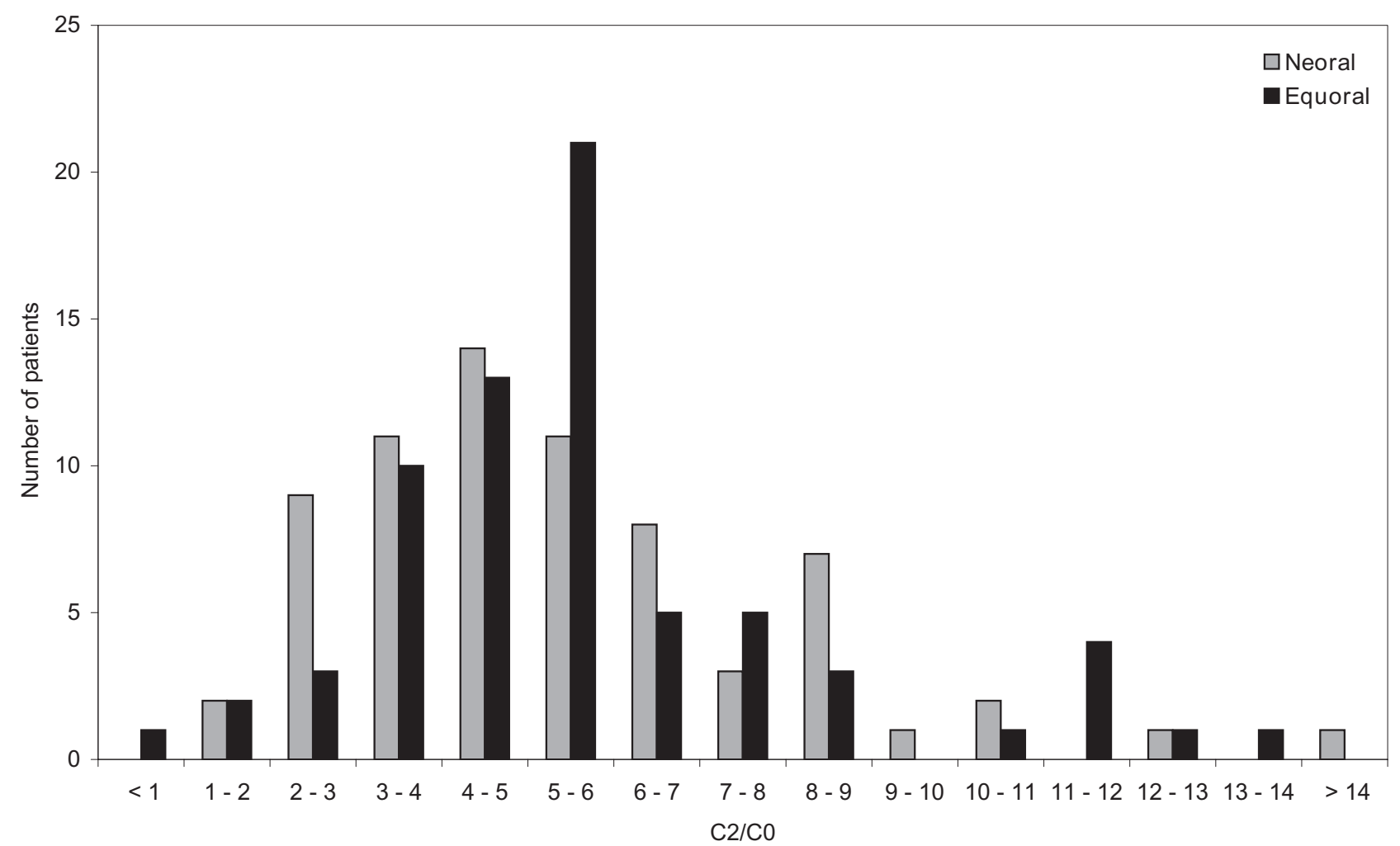

Fig. 3. Distribution of $\mathrm{C}_{2} / \mathrm{C}_{0}$ values in stable adult renal transplant recipients.

- Relative bioavailability: $\mathrm{F}_{\text {rel }}=$ Mean AUC $\tau$ test/ Mean $\mathrm{AUC} \tau$ reference

Computations were performed by means of the KINBES module (version 1.34) of the MW/PHARM software (version 3.30)?

The data were evaluated by geometric mean, standard deviation (SD) and median.

The decision in favour of bioequivalence was based on inclusion of the shortest $90 \%$-confidence interval for the ratio of medians in the respective bioequivalence range $0.8-1.25$.

Significance of the intraindividual differences was tested used a paired t-test and analysis of variance at $\mathrm{p}=0.05$.

\section{RESULTS}

Seventy stable adult renal transplant recipients [48 males, 22 females; mean age 35.3males, 34.7 females] were admitted to the study. Average dosage of CyA was $183.9 \mathrm{mg}$ (SD 77.2). Individual patients were maintained on the same dose given as equally divided doses at $12-\mathrm{hr}$ intervals. Figure 2 gives the geometric means of the concentration/time profiles of the reference and test product. The median of maximal concentration after Neoral ${ }^{\circledR}$ is $1.5 \mathrm{~h}$ with a wide range from 1 to $4 \mathrm{~h}$. Corresponding results for Equoral ${ }^{\circledR}$ are $1.5 \mathrm{~h}$ with a range from 0.5 to $4 \mathrm{~h}$. Results of the statistical assessment of the rate and extent of absorption after multiple dose of CyA are presented in Table 1. The results are given as a geometric mean and the shortest $90 \%$-confidence interval for the percent ratio test/reference after logarithmic transformation of the pharmacokinetic characteristics. As can be seen from the Table 1,90\%-confidence interval is entirely in the bioequivalence range of 80 to $125 \%$.

The ANOVA showed that differences in the ratio $\mathrm{Neoral}^{\circledR} / \mathrm{Equoral}^{\circledR}$ for individual parameters were not significant among the centers. However, there was a significant difference of $\mathrm{C}_{\min }$ among centers (Anova; $\mathrm{F}=4.36$, $\mathrm{p}<0.05)$.

The mean of $t_{1 / 2 \mathrm{el}}$ of the compared formulations were almost identical (Neoral ${ }^{\circledR} 6.26$ h, Equoral ${ }^{\circledR} 6,31 \mathrm{~h}$ ). A relatively large inter-individual variability of these elimination characteristics was observed both for Neora $l^{\circledR}$ (range $2.13 \mathrm{~h}-13.96 \mathrm{~h}$ ) and Equoral ${ }^{\circledR}$ (range 3.10-12.12 h). Intraindividual differences were not significantly different ( $\mathrm{t}$-test $=0.13$ ).

The geometric mean of the $\mathrm{C}_{0}$ concentration after the Neoral ${ }^{\circledR}$ treatment was $123 \mathrm{ng} / \mathrm{ml}$ (range 20 to $447 \mathrm{ng}$ / $\mathrm{ml}$ ), after the Equoral ${ }^{\circledR}$ treatment it was $114 \mathrm{ng} / \mathrm{ml}$ (range 13 to $387 \mathrm{ng} / \mathrm{ml}$ ). The corresponding $\mathrm{C}_{2}$ were $604 \mathrm{ng} / \mathrm{ml}$ (range 122 to $1808 \mathrm{ng} / \mathrm{ml}$ ) after the Neoral ${ }^{\circledR}$ administration and $591 \mathrm{ng} / \mathrm{ml}$ (range 85 to $1592 \mathrm{ng} / \mathrm{ml}$ ) after the Equoral ${ }^{\circledR}$ administration. In the 70 stable renal transplant patients, the mean increase of $\mathrm{C}_{0}$ to $\mathrm{C}_{2}$ was by factor of 5.4 (SD 2.5) after the Neoral ${ }^{\circledR}$ administration, while after the Equoral ${ }^{\circledR}$ administration it was 5.7 (SD 2.5). The distribution of the $\mathrm{C}_{2} / \mathrm{C}_{0}$ levels in these patients is shown in Fig 3. Comparison of number of patients with different absorption profiles is summarized in Table 2. There 
was no significant difference in CyA absorption profile of patients after the compared formulations.

The monitored blood trough levels were not significantly changed during the trial (geometric means at screening $116.2 \mathrm{ng} / \mathrm{ml}$, day $18117.2 \mathrm{ng} / \mathrm{ml}$, and day 35 $116,1 \mathrm{ng} / \mathrm{ml}$, Anova; $\mathrm{F}=0,02, \mathrm{p}=0,98$ )

\section{CONCLUSION AND DISCUSSION}

The aim of a bioequivalence study is to demonstrate equivalence within the acceptance range regarded as clinically relevant. However, similarity between the averages in healthy human volunteers does not imply similarity within patients in real clinical usage. Pollard et all formulated a consensus statement regarding potential clinical impact of using different formulations of $\mathrm{CyA}\left(\mathrm{ref}^{4}{ }^{4}\right)$. The pharmacokinetic conversion study of the new generic formulation of CyA was performed to exclude the pharmacokinetic problems after conversion from the reference product. We followed the fundamental question: if a patient is allowed to switch between the formulations, how much will the variation in bioavailability increase?

In the clinical study, various pharmacokinetic parameters were used to address the question. Comparison of intrasubject variability of these parameters appears to be a good indicator of switchability ${ }^{8}$.

$\mathrm{CyA}$ is a drug with a narrow therapeutic window where monitoring of blood could be of tremendous help ${ }^{1}$. Efforts have been directed towards the development of a limited blood sampling strategy for the assessment of the AUC used for therapeutic monitoring 9 . In the past, standard blood trough level $\left(\mathrm{C}_{0}\right)$ monitoring has been used. Although this method is currently the routine strategy, after development of the new formulation of CyA, it has become evident that new markers of therapeutic efficacy and toxicity should be tested. The CyA concentration 2 hours after dosing has been shown to be the best single-point predictor of $\mathrm{AUC}_{0-4}$. The $\mathrm{C}_{2}$ time point has been shown to be more sensitive than $\mathrm{C}_{0}$ as a surrogate marker for the $\mathrm{AUC}_{0-4}$ of $\mathrm{Neoral}^{\circledR}$ in renal ${ }^{10,11}$, hepatic ${ }^{12}$, and cardiac $^{13}$ transplant recipients.

In our study the $\mathrm{C}_{0}$ drug level measurement correlated significantly with AUC $\tau$ both for Neoral ${ }^{\circledR}(r=0.83)$ and Equoral $^{\circledR}(r=0.85)$. A significant correlation of AUC $\tau$ was also found for $\mathrm{C} 2$ levels ( $\mathrm{r}$ for $\mathrm{Neoral}^{\circledR}=0.74, \mathrm{r}$ for Equoral $\left.^{\circledR}=0.76\right)$. The absorption profile of $\mathrm{C}_{2} / \mathrm{C}_{0}$ of compared formulation was not significantly different and the data are comparable to the profile described in the literature $^{14}$. It is clear that timing of the absorption phase of both formulations is comparable and predictable and therefore both $\mathrm{C}_{0}$ and $\mathrm{C}_{2}$ are also applied to the new formulation of CyA.
The pharmacokinetic conversion study of the new CyA formulation Equoral ${ }^{\circledR}$ in stable adult renal transplant recipients treated by Neoral ${ }^{\circledR}$ showed no differences in the safety parameters monitored.

The study also demonstrated that in the population studied there were no differences in the rate and extent of absorption of the compared formulations, Neoral ${ }^{\circledR}$ and Equoral ${ }^{\circledR}$. This is guaranteed to prevent transplant rejection, and it is also an essential prerequisite to avoid overexposure, which places the patient at risk of nephrotoxicity and infection.

\section{REFERENCES}

1. Jorga A, Holt DW, Johnston A (2004). Therapeutic drug monitoring of cyclosporine. Transplant Proc, 36, S396-S403.

2. Levy G, Burra P, Cavallari A, Duvoux C, Lake J., Mayer AD, Mies S, Pollard SG, Varo E, Villamil F, Johnston A (2002). Improved clinical outcomes for liver tranplant recipients using cyclosporine monitoring based on 2-hr post-dose levels $\left(\mathrm{C}_{2}\right)$. Transplantation, 73, 953-959.

3. McMillan, MA (1989). Clinical pharmacokinetics of cyclosporine. Pharmacol Ther, 42, 135-156.

4. Pollard S, Nashan B, Johnston A, Hoyer P, Belicky P, Keown P, Helderman H (2003). A Pharmacokinetic and clinical review of the potential clinical impact of using different formulations of cyclosporine A. Clin Ther, 25, 1654-1669.

5. Committee for Guidance on the Investigation of Bioavailability and Bioequivalence, CPMP, 2001.

6. Masri MA, Andrysek T, Matha V (2003). The role of generics in transplantation. Transplant Proc, 35, 2745-2747.

7. Proost JH, Meijer DKF (1992). MW/Pharm, an integrated software package for drug dosage regimen calculation and therapeutic drug monitoring. Comput Biol Med, 27, 155-163.

8. Benet LZ (1999). Understanding bioequivalence testing. Transplant Proc, 31, S7-S9.

9. Cole E, Maham N, Cardella C, Cattran D, Fenton S, Hamel J, O Grady C, Smith R. (2003) Clinical benefits of Neoral ${ }^{\circledR} \mathrm{C} 2$ monitoring in the long-term management of renal transplant recipients, Transplantation, 75, 2086-2090

10. Mahalati K, Belitsky P, Sketris I, West K, Panek R (1999). Neoral monitoring by simplified sparse sampling area under the concentration-time curve: Its relationship to acute rejection and cyclosporine nephrotoxicity early after kidney transplantation., Transplantation, $68,55-62$.

11. International Neoral Renal Transplantation Study Group (2002). Cyclosporine microemulsion $\left(\mathrm{Neoral}^{\circledR}\right)$ absorption profiling and sparse-sample predictors during the first 3 months after renal transplantation. Am J Transplant, 2, 148.

12. Grant D, Kneteman N, Tchervenkov J, Roy A, Murphy G, Tan A, Hendricks L, Guilbault N, Levy G (1999). Peak cyclosporine levels $\left(\mathrm{C}_{\max }\right)$ correlate with freedom from liver graft rejection: Results of a prospective, randomized comparison of Neoral and Sandimmune for liver transplantation (NOF-8). Transplantation, 67, 1133-1137.

13. Cantarovich M, Besner JG, Barkun JS, Elstein E, Loertscher R (1998) Two-hour cyclosporine level determination is the appropriate tool to monitor Neoral therapy. Clin Transplant, 12, 243-249.

14. Einecke G, Mai I, Diekmann F, Fritsche L, Neumayer HH, Budde $\mathrm{K}$ (2002). Cyclosporine absorption profiling and therapeutic drug monitoring using $\mathrm{C}_{2}$ blood levels in stable renal allograft recipients, Transplant Proc, 34, 1738-1739. 